\section{NEW PRODUCTS AND FOCUS ON ORAL HEALTH AND ORTHODONTICS}

Please send product news information and images to David Westgarth at the BDJ, Nature Publishing Group, The Macmillan Building, 4-6 Crinan Street, London, N1 9XW. Product news is provided as a service to readers using text and images from the manufacturer, supplier or distributor and does not imply endorsement by the $B D J$. Normal and prudent research should be exercised before purchase or use of any product mentioned.

\section{CELEBRATING INITIAL MILESTONES}

After only a couple of months since the announcement of its launch, the European Aligner Society (EAS) is already celebrating several exciting milestones as it progresses towards fulfilling its initial aims. The Society was created to provide continuing information about developments in clear aligner therapy, and develop a strong backup to the formal training that takes place at postgraduate level.

As an over-arching members' Association, EAS aims to provide membership services which will form the basis of the 'aligner' community; provide support to members; offer advice and guidance; and make resources available to support and develop education in clear aligner therapy. The EAS will formally launch at the World Federation of Orthodontists Congress at Excel in London between 27-30 September 2015. Potential members are invited to visit stand 548 to meet the
Society founders and sign up.

As part of its remit to provide education in aligner therapy, the EAS' first live one-hour webinar 'Aligner Therapy and Biomechanics' was presented by the Society President Dr Graham Gardener in mid-June. This can now be viewed free of charge on the education page of the EAS website www.eas-aligners.com/education.

Membership of EAS is open now. As an incentive to clinicians to support EAS, a subscription for the first year will only require renewal a year after the formal launch - September 2016. Visit www.eas-aligners.com to join the Society now.

\title{
AN INNOVATIVE SOLUTION TO HELP WITH PLAQUE MANAGEMENT
}

Plaque is a major cause of gum dis-

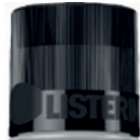
ease ${ }^{1}$ and according to the Group B consensus report of the fifth European Workshop in

Periodontology, '...oral plaque biofilm disruption is the most effective way to treat and prevent both conditions [gingivitis and periodontitis]'.2

In line with this, LISTERINE Advanced Defence Gum
Treatment is clinically proven to interrupt the plaque colonisation process. ${ }^{3}$

It is formulated with unique LAE (ethyl lauroyl arginate) technology that forms a physical coating on the pellicle to prevent bacteria attaching, and so interrupts biofilm formation. When used after brushing it treats gum disease, as indicated by the reduction of bleeding by $50.9 \%$ ( $p<0.001$ ) in only 4 weeks. ${ }^{3}$ Advanced Defence Gum Treatment is part of the LISTERINE Advanced Defence range from Johnson \& Johnson, a scientifically proven adjunct to your professional treatment.

For more details on LISTERINE Advanced Defence visit www.listerineprofessional.co.uk or call 08003280750.

1. Page R C, Kornman K S. The pathogenesis of human periodontitis: an introduction. Periodontol 2000 1997; 14: 9-11.

2. Kinane $D F$, Attstrom R. Advances in the pathogenesis of periodontitis. Group B consensus report of the fifth European Workshop in Periodontology. J Clin Periodontol 2005; 32(Suppl.6): 130-131.

3. Bleeding Index Reduction DOF 1 - 2013 (LAEBBA0001), 50.9\% Reduction in whole-mouth mean Bleeding Index at 4 weeks.

\section{THE SYSTEM OF CHOICE}

DENTSPLY have further strengthened their Palodent brand by combining two of their strongest matrix systems - Palodent Plus and Triodent V3 - under the new name of Palodent V3.

For dentists placing Class II restorations Palodent V3 is the reliable sectional matrix system of choice for predictable and accurate contacts, and can be used with any restorative material, including composites, amalgams, wax patterns or temporaries.

The new and easy-to-use Palodent V3 system retains all the familiar benefits that dentists expect when striving for natural contours and profiles:

- Predictable accurate contacts

- Tight gingival seal

- Minimised flash and finishing

- Micro-thin, non-stick EZ Coat for effortless matrix placement and removal.

Palodent V3 is the new name in effective design, technology and patient comfort to help dentists overcome the challenges that come with Class II restorations.

To find out more about Palodent V3, contact DENTSPLY on 08000723313 or visit dentsply.co.uk. 